\title{
Model Konseling Islam untuk Rehabilitasi Korban Penyalahgunaan Narkoba
}

\author{
Maulida Aulia Rahman* \\ Jurusan Bimbingan dan Konseling Islam, UIN Sunan Gunung Djati, Bandung \\ *Email : maulida.aulia80@gmail.com
}

\begin{abstract}
This paper aims to determine the condition of victims of drug abuse, the model of Islamic counseling that is applied and the results of its application. The research method used qualitative descriptive method involving data source from the caretaker Pondok Remaja Inabah XIV Garut, counselor, and anak bina that directly related to the research focus. The results of this study indicate that the condition of victims of drug abuse is negatively affected both biologically, psychologically, socially, and spiritually. The model of Islamic counseling for the rehabilitation of victims of drug abusers in Pondok Remaja Inabah XIV Garut is included in the model of personality development as well as the model of countermeasures that has elements of the model that is the rationale, vision, mission and goals, methods and techniques, materials, media, stages and processes, and evaluation. The result of the implementation of Islamic counseling model for the rehabilitation of drug abuse victims in Pondok Remaja Inabah XIV Garut is shown with positive condition of the children of bina both biologically, psychologically, socially, and spiritually.
\end{abstract}

Keywords: Islamic Counseling Model; Rehabilitation; Victims of Drug Abuse

\begin{abstract}
ABSTRAK
Tulisan ini bertujuan untuk mengetahui kondisi korban penyalahgunaan narkoba, model konseling Islam yang diterakan serta hasil penerapannya. Metode penelitian menggunakan metode deskriptif kualitatif yang melibatkan sumber data dari pembina Pondok Remaja Inabah XIV Garut, pembimbing/konselor, dan anak bina yang berkaitan langsung dengan fokus penelitian. Hasil penelitian ini menunjukan bahwa kondisi korban penyalahgunaan narkoba terkena dampak negatif baik secara biologis, psikokogis, sosial, serta spiritual. Model konseling Islam untuk rehabilitasi
\end{abstract}

Diterima: Januari 2019. Disetujui: Februari 2019. Dipublikasikan: Maret 2019. 


\section{A. Rahman}

korban penyalahguna narkoba di Pondok Remaja Inabah XIV Garut termasuk pada model perkembangan kepribadian serta model penaggulangan yang memiliki unsur-unsur model yaitu dasar pemikiran, visi, misi dan tujuan, metode dan teknik, materi, media, tahapan dan proses, serta evaluasi. Hasil penerapan model konseling Islam untuk rehabilitasi korban penyalahgunaan narkoba di Pondok Remaja Inabah XIV Garut ditunjukan dengan kondisi positif anak bina baik secara biologis, psikologis, sosial, dan spiritual.

Kata Kunci : Model Konseling Islam; Rehabilitasi; Korban Penyalahgunaan Narkoba

\section{PENDAHULUAN}

Indonesia darurat narkoba, Indonesia sedang menghadapi permasalahan yang sangat kompleks, salah satu permasalahan tersebut yaitu peredaran obat obatan terlarang atau biasa disebut narkoba. Permasalahan penyalahgunaan narkoba mempunyai dimensi yang luas dan kompleks, baik dari sudut medik, psikiatrik, kesehatan jiwa maupun psikososial (ekonomi, politik, sosial budaya, kriminalitas dan sebagainya). Penyalahgunaan narkoba merupakan fenomena sosial yang telah menjadi masalah sosial. Narkoba dan sejenisnya merupakan fenomena yang sudah ada sejak jaman dulu seiring munculnya perkembangan peradaban manusia di muka bumi ini (Kibtyah, 2015: 53).

Dalam ringkasan eksekutif hasil survei BNN tahun 2016 dikatakan menurut UNODC (United Nation Office on Drugs and Crime) pada tahun 2015 bahwa prevalensi penyalahgunaan narkoba di dunia sejak tahun 2006 hingga 2013 mengalami peningkatan. Besaran prevalensi penyalahgunaan di dunia diestimasi sebesar 4,9\% atau 208 juta pengguna di tahun 2006 kemudian mengalami sedikit penurunan pada tahun 2008 dan 2009 menjadi 4,6\% dan 4,8\%. Namun kemudian meningkat kembali menjadi 5,2\% di tahun 2011 dan tetap stabil hingga 2013. Secara absolut, diperkirakan ada sekitar 167 hingga 315 juta orang penyalahguna dari populasi penduduk dunia yang berumur 15-64 tahun yang menggunakan narkoba minimal sekali dalam setahun di tahun 2013 (BNN-PUSLITKES UI, 2017: 2).

Angka prevalensi penyalahgunaan narkoba di Jawa barat mencapai 2,42 persen. Angka tersebut setara dengan sekitar 850-900 jiwa penduduk. Selain itu, peredarannya di Tatar Priangan menduduki peringkat ke enam di Indonesia dengan diperkirakan setiap hari sebanyak 8-9 orang meninggal dunia akibat narkoba. Demikian terungkap saat Sosialisasi 'Sadar Bahaya Narkoba Bersama Bank BRI' yang digelar BRI Kanwil Bandung bekerjasama dengan Badan Narkotika Nasional Provinsi (BNNP) Jawa Barat, di Gedung BRI Kanwil Bandung, Selasa 29 Agustus 2017.

Sebagai obat-obatan yang memiliki daya agar para pemakainya tidak 
sadarkan diri narkoba juga memiliki kekuatan yakni membuat candu para pemakainya. Dari beberapa kasus yang ada, salah satunya adalah coba-coba. Rasa keingintahuan yang berlebihan pada remaja sekarang membuat mereka mencoba barang haram tersebut. Baik Berasal dari pengaruh individu itu sendiri maupun dari faktor eksternal dan faktor lingkungan meliputi faktor pergaulan lingkungan keluarga, sekolah, teman sebaya, lingkungan masyarakat / sosial. Dari awal coba-coba dapat meningkat sebagai pecandu. Dari sanalah awal kehancuran masa depan mereka dipertaruhkan. Bukan hanya kematian yang menjadi dampak mengkhawatirkan bagi korban penyalahgunaan narkoba, akan tetapi juga dampak bagi masa depan.

Para korban penyalahgunaan narkoba dipandang sebelah mata dan berkesan buruk bagi lingkungannya sehingga ia dikucilkan dari lingkungannya. Hal ini terus-menerus terjadi pada diri individu (pengguna narkoba) maka sering kali kegoncangan dalam jiwanya yang pada akhirnya akan mengganggu kesehatan mentalnya. Salah satunya kecemasan menghadapi masa depan yang berkaitan dengan emosi yang tidak menyenangkan yang terkait dengan berbagai masalah yang harus dihadapi dalam masa perkembangannya yang berpengaruh pada aspek afektif, aspek kognitif, dan aspek perilaku. Masalah yang menjadi sumber kecemasan dalam menghadapi masa depan berkaitan dengan masalah pendidikan, pekerjaan, keluarga.

Salah satu usaha untuk menanggulangi korban penyalahgunaan narkoba ini adalah dengan didirikannya pusat-pusat rehabilitasi untuk para korban penyalahgunaan narkoba. Pusat rehabilitasi tersebut bertujuan untuk membantu menumbuhkan kembali rasa kesadaran dan tanggung jawab bagi para korban penyalahgunaan narkoba terhadap masa depannya, keluarga dan sekitarnya. Pondok Remaja Inabah XIV Garut merupakan salah satu tempat rehabilitasi bagi para korban penyalahgunaan narkoba. Dasar pemikiran yang bersifat religi dan menekankan pada pemulihan diri para korban agar lepas dari ketergantungan dari narkoba melalui pendekatan secara islami.

Hasil dari penulusuran yang dilakukan, terdapat hasil penelitian terdahulu yang membahas mengenai Model Konseling Islam untuk Rehabilitasi Korban Penyalahgunaan Narkoba yang mengungkapkan metode bimbingan keagamaan yang dilakukan oleh K.H Dahlan Saepulloh terhadap pengguna NAPZA diantaranya terdapat metode wawancara, group guidance, directive, non directive, dan psikoanalisis, dan terdapat empat teknik yang khusus dipakai yaitu doa, dzikir, shalat, dan hipnoterapi. Adapun hasil-hasil yang dicapai oleh K.H Dahlan Saepulloh dalam bimbingan keagamaannya, kebanyakan klien dapat berhasil disembuhkan dengan catatan semua klien yang datang harus mengikuti anjurananjurannya. Rata-rata kesembuhan kliennya antara 7 - 40 hari (Cucu, 2009: 112).

Adanya konseling Islam bagi korban penyalahgunaan narkoba diharapkan 


\section{A. Rahman}

akan membentuk kehidupan yang baik, membina akidah, membina kepribadian, mengetahui hak dan kewajiban bermasyarakat. Untuk menjadikan putra-putri bangsa ini menjadi manusia yang lebih berguna baik bagi nusa, bangsa, dan agama. Yayasan ini menerapkan suatu metode bimbingan keagamaaan dengan membiasakan para anak bina didalamnya mengikuti pembinaan keagamaan dalam hal ini konseling Islam, sebagai target agar anak binaan yang merupakan korban penyalahgunaan narkoba tersebut tidak sebatas hanya sembuh secara medis atau psikologis pada umumnya, melainkan diharapkan mampu menjadi manusia yang "Arif billahi" atau menjadi manusia yang mengenal kepada Allah SWT, yang mempunyai kepribadian religius dan trasendentalis.

Berdasarkan penelitian terdahulu yang sudah dilakukan oleh Gudnanto (2015) model Bimbingan dan Konseling Islami fokus pada peningkatan konsep diri siswa. Sedangkan konsep diri yang akan ditingkatkan adalah konsep diri (selfconcept) tiga bagian utama yaitu: (1) Self-Ideal (Diri Ideal), (2) Self-Image (Citra Diri), dan (3) Self-Esteem (Harga Diri). Ketiga elemen tersebut merupakan satu kesatuan yang membentuk kepribadian. Menentukan apa yang biasa kita pikir, rasakan, dan lakukan, serta akan menentukan segala sesuatu yang terjadi kepada diri individu. Selanjutnya, menurut Farid (2015) model bimbingan konseling Islam pada kenakalan remaja menurut pemikiran Anwar Sutoyo kenakalan remaja itu bermacam-macam yang dihadapi oleh para remaja, akibat perubahanperubahan yang terjadi pada dirinya baik dari jasmani maupun rohaninya. Adapun penelitian yang dilakukan oleh Nisa (2017) ditemukan bahwa bimbingan dan konseling psikoanalisis berbasis Islam untuk mengurangi kecemasan moral pada remaja. Perbedaan dengan penelitian yang dilakukan oleh peneliti terletak pada objek penelitiannya.

Dari latar belakang masalah tersebut dapat dirumuskan beberapa rumusan masalah: bagaimana kondisi anak bina (korban penyalahgunaan narkoba) baik sebelum maupun sesudah diberikannnya program rehabilitasi serta model dan hasil konseling islam untuk rehabilitasi korban penyalahgunaan narkoba di Pondok Remaja Inabah XIV Garut?

Metode yang digunakan dalam penelitian ini adalah deskriptif kualitatif, dengan menganalisis hasil pengumpulan data melalui observasi dan wawancara dengan konselor sekaligus pembina, serta konseli/anak bina di Pondok Remaja Inabah XIV Garut.

\section{LANDASAN TEORITIS}

Teori yang menjadi landasan penelitian ini adalah teori model bimbingan konseling Islam dalam proses pelaksanaan rehabilitasi korban penyalahgunaan narkoba. Model merupakan acuan dari suatu kerangka berpikir tertentu (Winkel, 1997:129), sedangkan model bimbingan yang mengacu pada kegiatan konseling 
itu sendiri ialah suatu pola atau suatu contoh kerja sistematis dan umum atau suatu bentuk penyampaian pengetahuan atau pemberian bimbingan tertentu dari suatu ilmu agar yang dibimbing dapat mengetahui, memahami, mempergunakan, serta tergerak mengamalkannya (Darajat, 2011: 1).

Penelitian ini juga mengacu pada macam model bimbingan yang disebut oleh Ralph Muer dan Norman A. Spinal yaitu model bimbingan seseorang (personal development) mengenai kesehatan mental dan mengatasi krisis batin dengan membentuk tim khusus, serta model penanggulangan yang disebut $\mathrm{J}$. Manacher sebagai model penanggulangan segala gejala pemberontakan tingkah laku pada tempat/kelompok tertentu seperti tempat kumuh dan miski, penjara atau tempat para pecandu obat terlarang dengan memberikan bimbingan penanggulangan dan perhatian (Winkel, 1997: 120-129).

Konseling Islam merupakan salah satu upaya pemecahan masalah dengan memberikan bantuan kepada orang yang mengalami kesulitan, baik lahir maupun batin, yang menyangkut kehidupan sekarang maupun kehidupan yang akan datang. Bantuan tersebut berupa pertolongan dibidang mental spiritual, dengan maksud agar orang mampu menyelesaikan permasalahannya dengan kemampuan yang ada pada dirinya, dengan kekuatan iman dan taqwa kepada Allah SW'T (Arifin, 1982: 2). Karena itulah Korban penyalahgunaan narkoba hakikatnya memerlukan bimbingan, bantuan, dan pertolongan untuk perawatan, penyembuhan guna menumbuhkan kembali Akbláq-al-Karimah, meningkatkan ketaqwaan, dan terlepas dari bayang-bayang Narkoba, serta ingat kepada Sang Penciptanya, yakni Allah SWT.

Dengan demikian, konseling Islam perlu diberikan kepada klien agar mereka dapat menumbuhkan dan meningkatkan kesadaran beragama, dan mengetahui pembinaan agamanya yang selama ini mereka cenderung tinggalkan. Agar potensi keagamaan melalui keimanan dan ketaqwaan dapat dijadikan penggerak pribadi manusia, maka perlu digerakkan dengan berbagai metode yang bersifat psikologis sebagaimana dalam bukunya Samsul Munir (2010: 362) metode yang bisa di pakai dalam bimbingan adalah (a) wawancara, (b) group guidance, (c) direktif, (d) non direktif. Maka jelaslah pengaruh bimbingan keagamaan dapat menjadikan manusia itu sebagai hamba Allah yang mampu berjalan di jalan yang benar sesuai dengan petunjuk-Nya. Oleh karena itu, pendekatan dari segi agama inilah yang paling penting bagi pelaksanaan program bimbingan keagamaan ini (Samsul Munir, 2010: 44).

Berdasarkan teori-teori yang telah di uraikan, bahwa pelaksanaan yang cocok untuk digunakan sebagai model rehabilitasi korban penyalahgunaan narkoba adalah model konseling Islam yang terdiri dari unsur-unsur model yang teridi dari : (1) Dasar Pemikiran; (2) Visi, Misi, dan Tujuan; (3) Metode dan Teknik; (4) Materi; (5) Media; (6) Proses dan Tahapan; (7) Evaluasi. 


\section{A. Rahman}

Pertama, dasar pemikiran. Penyalahgunaan narkoba bukan hanya dipandang sebagai kejahatan, namun merupakan penyakit moral masyarakat. Pelakunya tidak lagi dipandang sebagai kriminal, melainkan sebagai korban, yaitu penderita yang memerlukan pertolongan. Oleh karena itu sikap yang tepat terhadap penyalahguna narkoba adalah dengan terapeutik atau rehabilitasi. Rehabilitasi yang diberikan haruslah yang komprehensif, artinya rehabilitasi yang diberikan tidak hanya secara fisik saja tetapi aspek psikologis (mental), dan sosial juga harus diberikan (UU RI Tentang Narkotika No. 35 Th 2009 Bab I Pasal 1 tentang Rehabilitasi Sosial). Hal ini dikarenakan keadaan mental penyalahguna narkoba baik yang masih dalam masa rehabilitasi maupun yang sudah sembuh memiliki perbedaan dengan yang lainnya.

Kedua, visi dari adanya konseling Islam ialah mewujudkan, serta mengantarkan individu mengenal, mencintai, dan berjumpa dengan esensi diri dan citra diri serta żat yang maha suci yaitu Allah SWT agar mencapai kebahagiaan hidup di dunia dan di akhirat (Adz-Dzaky, 2006: 228). serta misinya (1) Meningkatkan pembinaan yang dinamis agar keimanan mereka tidak statis atau bahkan turun sehingga tetap mengalami perbaikan (meningkat terus menerus); (2) Meningkatkan pemberian materi ibadah adalah untuk mengetahui kemampuan dan keaktifan klien dalam mengaplikasikan materi ibadah yang telah di terima. Materi ibadah tepat sekali disampaikan karena dapat dijadikan sebagai evaluasi terhadap kemampuan dan keaktifan pasien dalam menjalankan ibadah, seperti salat, żikir, dan do ${ }^{\text {"e }}$ sehari-hari; (3) Meningkatkan pengajaran tentang bentuk batin seseorang yang kelihatan pada tingkah lakunya. Dalam arti yang lebih dalam materi tersebut berkaitan dengan akhlak selaku hamba kepada Allah SWT, akhlak terhadap dirinya sendiri, akhlak sebagai manusia terhadap manusia yang lain, akhlak terhadap binatang, dan akhlak terhadap makhluk Allah SWT. yang lainnya (Abidin, 2003: 60).

Ketiga, metode dan teknik konseling Islam didasarkan kepada Al-Quran dan Sunnah. Proses perawatannya disebut dengan istilah Istisyfa. Fokus metode yang diganakan ialah metode ibadah yang digunakan dalam bimbingan dan konseling Islami pada penderita kelainan mental yang terdiri dari Al-istisyfa bil Qur'an, do'a, mandi terapi, metode zi ikir dengan terapi, salat untuk terapi, puasa untuk terapi, metode hikmah, metode tarikat dan tasawuf (Arifin, 2009: 31). Dengan fokus strategi layanan konseling dengan konseling individu yang dalam istilah konseling islam disebut dengan irsyad fardiyah.

Keempat, materi bimbingan dan konseling Islami yang diberikan pada dasarnya bersumber pada Al-Qur'an dan Al-Hadiś. Materi yang disampaikan bertujuan untuk memberikan bimbingan atau pengajaran ilmu yang bersumber pada ayat Al-Qur'an dan Al-Hadiś. Materi yang digunakan dalam menangani kelainan mental berhubungan dengan aqidah (tauhid), ibadah, dan akhlak (budi 
pekerti) (Lubis, 2007:100).

Kelima, media/bentuk washilah dalam dakwah (termasuk dalam kegiatan irsyad/Konseling Islam) yaitu media secara maknawiyah yaitu persiapan prapelaksanaan seperti mencari materi yang baik, serta waktu dan tempat guna pelaksanaan bimbingan konseling dan media secara madiyah yaitu peralatan fisik yang dibutuhkan ketika pelaksanaan bimbingan konseling/dakwah (Hasyim, 2010: 29).

Keenan, Langkah-langkah konseling Islam yang dilakukan terbagi dalam tahapan inti dan penunjang. Dalam tahapan inti terdapat tiga fase pelayanan, dengan harapan konseli dapat pulih secara optimal. Fase I merupakan fase pemulihan kesadaran dan pembersihan diri. fase II merupakan fase pengisian jiwa dengan segala amal baik dan aktivitas-aktivitas ruhaniyah dan optimalisasi amaliyah ibadah. Pada fase III ini merupakan fase pemantapan amaliyah ibadah agar klien dapat istiqomah dalam kebajikan dengan keikhlasan dan kekhusuyuan ibadah (Saepulrahim, 2016: 150).

Ketujuh, evaluasi. Sebuah penanganan konseling Islam membutuhkan evaluasi, agar permasalahan yang telah dipecahkan benar-benar ditindak lanjuti oleh pasien. Pemecahan yang berupa solusi agar keluar dari permasalahan tidak akan berjalan jika tidak ditindak lanjuti. Oleh karena itu, diperlukan pelayanan untuk menindak lanjuti pemecahan masalah yang diberikan oleh pembimbing (Amin, 2010: 121).

\section{HASIL DAN PEMBAHASAN}

Penelitian ini dilakukan di Pondok Remaja Inabah XIV Yayasan Serba Bakti Pondok Pesantren Suryalaya Perwakilan Garut terletak di Jalan Raya Bayongbong Kp. Padarek RT/RW 003/006 Desa Sirnagalih Kec. Bayongbong Garut. Tempat dengan papan nama yang terlihat jelas dan strategis di Jalan Raya Bayongbong, dan tepat sebelum belokan Kp. Padarek akan mudah dijumpai ketika hendak menuju lokasi Pondok Pesantren ini. Pondok Remaja Inabah XIV Yayasan Serba Bakti Pondok Pesantren Suryalaya Perwakilan Garut ini telah ada sejak tahun 1986 hingga sekarang.

Sejak awal tahun 2017 jumlah santri di Pondok Remaja Inabah XIV mencapai 10 - 13 anak bina, akan tetapi dikarenakan keluar masuk santri yang dikarenakan berbagai alasan, sehingga tidak ada data kongkrit berapa jumlah santri. Anak bina Pondok Remaja Inabah XIV seluruhnya laki-laki. Untuk rentang usia anak bina yang terdapat di Pondok Remaja Inabah XIV ini didominasi dengan klien yang masih dalam usia yang sangat muda, dari mulai pelajar, mahasiswa, dan pemuda di usia produktif lainnya. Anak bina dengan usia produktif lebih dominan dari pada usia yang kurang produktif. Karena dalam rangka pencarian jati diri, pemuda terkadang salah ambil jalan. Sehingga 


\section{A. Rahman}

akibatnya mereka menyalahgunakan narkoba dan jauh dari agama.

Sarana prasarana yang terdapat di Pondok Remaja Inabah yang ada untuk menunjang pada aktivitas pembinaan ini yaitu adanya Masjid (sebagai sarana Ibadah), Ruang Pertemuan, Ruang Makan, Ruang Knator dan Kesekretariatan, Ruangan Besar untuk berkumpulnya anak bina, dua Kamar Mandi, tempat wudlu, dan MCK, dan satu ruangan konseling. Hasil penelitian ini mengemukakan kondisi anak bina di Pondok Remaja Inabah XIV Garut, model konseling Islam yang diterapkan, dan hasil dari penerapannya.

\section{Kondisi Anak Bina}

Pada umumnya hal yang mempengaruhi anak bina terjerumus ke dalam penyalahgunaan narkoba terjadi motif yang berbeda-beda dari anak bina yang satu dengan yang lain. Faktor penyebab yang paling dominan terjadinya penyalahgunaan narkoba adalah pengaruh faktor lingkungan.

Bukan hanya itu masalah yang ada saat para pecandu ini memakai narkoba, akan tetapi keluarga sabagai lingkungan paling bepengaruh ini juga merasakan dampak sosial. Maka yang terjadi adalah mereka tidak langsung melakukan tindakan medis atau yang lain, akan tetapi ada yang bersifat apatis, serta marahmarah saat melihat anggota keluarganya menggunakan narkoba.

Terdapat beberapa faktor yang melatar belakangi penyalahgunaan narkoba, di antaranya adalah: pertama, faktor predisposisi, yang termasuk faktor predisposisi adalah gangguan kepribadian anti sosial, kecemasan, depresi. Adapun dampak yang ditimbulkannya (kriminalitas, amoral, antisosial) adalah merupakan bentuk dari katarsis atau pelampiasan dari depresi yang dia alami.

Kedua, faktor kontribusi, yang termasuk faktor kontribusi adalah kondisi keluarga, keutuhan keluarga, kesibukan orang tua dan hubungan interpersonal. Dengan kata lain kondisi keluarga yang kurang baik misalnya kematian orang tua, kedua orang tua bercerai, hubungan kedua orang tua tidak harmonis, hubungan orang tua dengan anak tidak baik, suasana rumah tangga yang tegang, suasana rumah tangga tanpa kehangatan, orang tua sibuk dan jarang di rumah merupakan salah satu faktor penyebab orang menyalahgunakan narkoba.

Ketiga, faktor pencetus, yang termasuk faktor pencetus adalah lingkungan dan teman kelompok. Teman kelompok dapat menciptakan keterikatan dan kebersamaan sehingga yang bersangkutan sukar melepaskan diri. Teman kelompok biasanya adalah orang yang pertama kali mengenalkan narkoba bahkan merupakan kelompok yang menyebabkan seseorang tetap menyalahgunakan narkoba.

Tabel 1. Kondisi Anak Bina Sebelum Rehabilitasi

Aspek Kondisi

Kondisi Biologis

92

\section{Ciri-Ciri Kondisi}

Gangguan pada system syaraf (neurologis) seperti: kejang-kejang, halusinasi, gangguan kesadaran.

Irsyad : Jurnal Bimbingan, Penyuluhan, Konseling, dan Psikoterapi Islam 7(1) (2019) 85-104 
Gangguan pada kulit (dermatologis) seperti: penanahan (abses), alergi, eksim.

Gangguan pada paru-paru (pulmoner) seperti: penekanan fungsi pernapasan, kesukaran bernafas.

Sering sakit kepala, mual-mual dan muntah, murus-murus, suhu tubuh meningkat, dan sulit tidur.

Kondisi Psikologis Lamban kerja, ceroboh kerja, sering tegang dan gelisah

Hilang kepercayaan diri, apatis, pengkhayal, penuh curiga

Agitatif, menjadi ganas dan tingkah laku yang brutal

Sulit berkonsentrasi, perasaan kesal dan tertekan

Kondisi Sosial Anti-sosial dan asusila, dikucilkan oleh lingkungan.

Merepotkan dan menjadi beban keluarga

Pendidikan menjadi terganggu, dan berpikir memiliki masa depan yang suram

Kondisi Spiritual Tidak Percaya adanya Allah

Tidak pernah dan tidak mengetahui tata cara pelaksanan ibadah

Sumber: Hasil wawancara dan observasi.

Tabel diatas menyebutkan berbagai macam dampak yang disebabkan oleh penyalahgunaan narkoba. Di antaranya adalah dampak terhadap diri sendiri, dampak terhadap lingkungan, dan dampak terhadap bangsa.

Dampak narkoba bagi diri sendiri di antaranya adalah: pertama, terganggunya fungsi otak dan perkembangan remaja seperti daya ingat, perhatian, perasaan, persepsi, dan motivasi yang menurunkan minat belajar, persahabatan rusak, dan cita-cita menjadi padam. Kedua, Intoksidasi atau keracunan, dikarenakan obat yang digunakan sangat berpengaruh pada tubuh (obat keras). Ketiga, overdosis (OD), dikarenakan kelebihan jumlah dosis narkoba yang dikonsumsi yang tidak jarang menyebabkan kematian. Keempat, gangguan perilaku atau mental-sosial, seperti acuh tak acuh, sulit mengendalikan diri, mudah tersinggung, marah, menarik diri dari pergaulan. Kelima, dan terserangnya HIV/AIDS.

Dampak terhadap keluarga. Suasana nyaman dan tenteram terganggu. Keadaan ekonomi semakin menurun karena habis untuk membeli narkoba. Barangbarang di rumah banyak yang hilang dicuri untuk memenuhi hasrat narkoba. Orang tua malu karena mempunyai anak seorang pecandu narkoba, masa depannya tidak jelas, putus sekolah atau menganggur.

Dampak terhadap bangsa. Mafia perdagangan gelap selalu berusaha 


\section{A. Rahman}

memasok narkoba. Terjalin hubungan pengedar dengan korban dan tercipta pasar gelap. Oeh karena itu sekali pasar terbentuk, sulit untuk memutus mata rantai peredarannya. Masyarakat yang rawan narkoba tidak memiliki daya tahan sehingga kesinambungan pembangunan terancam. Bangsa akan mengalami kerugian karena masyarakatnya tidak produktif, tingkat kejahatan meningkat.

Mental manusia pada dasarnya dapat diklasifikasikan menjadi dua, pertama adalah mental yang sehat, yaitu terhindar dari segala gangguan dan penyakit jiwa (mental). Kedua adalah mental yang tidak sehat; yaitu mental yang telah mengalami gangguan, seperti: sering cemas tanpa diketahui sebabnya, malas, tidak ada gairah untuk bekerja, rasa badan lesu, dan sebagainya. Jika manusia memiliki mental yang pertama, maka segala sikap dan tindakannya akan mengarah kepada kebaikan (positif) tetapi bila manusia memiliki mental yang kedua, maka segala sikap dan perbuatannya akan cenderung pada halhal yang buruk (negatif). Untuk membentuk mental yang sehat, diperlukan adanya pembinaan mental yang baik dan dapat dipertanggung jawabkan, ini tidak dapat dilepaskan dengan keberadaan manusia sebagai makhluk yang mempunyai keterikatan pada dirinya, Tuhan, dan masyarakat sosial.

Secara fisik, tubuh para penyalahguna akan mengalami ketergantungan dan sel-sel tubuh, organ-organ vital dalam tubuh seperti liver, jantung, paru-paru, ginjal,dan otak juga mengalami kerusakan akibat penggunaan jangka panjang narkoba. Banyak sekali pecandu narkoba yang berakhiran dengan katup jantung yang bocor, paru-paru yang bolong, gagal ginjal, serta liver yang rusak. Belum lagi kerusakan fisik yang muncul akibat infeksi virus \{Hepatitis $\mathrm{C}$ dan HIV/AIDS \} yang sangat umum terjadi di kalangan pengguna jarum suntik.

Selain ketergantungan fisik, terjadi juga ketergantungan mental. Ketergantungan mental ini lebih susah untuk dipulihkan daripada ketergantungan fisik. Ketergantungan yang dialami secara fisik akan lewat, tetapi setelah itu akan muncul ketergantungan mental, dalam bentuk yang dikenal dengan istilah 'sugesti'. Orang seringkali menganggap bahwa sakaw dan sugesti adalah hal yang sama, ini adalah anggapan yang salah. Sakaw bersifat fisik, dan merupakan istilah lain untuk Gejala Putus Obat, sedangkan sugesti adalah ketergantungan mental, berupa munculnya keinginan untuk kembali menggunakan narkoba. Sugesti ini tidak akan hilang saat tubuh sudah kembali berfungsi secara normal. Sugesti ini bisa digambarkan sebagai suara-suara yang menggema di dalam kepala seorang pecandu yang menyuruhnya untuk menggunakan narkoba. Sugesti seringkali menyebabkan terjadinya 'perang' dalam diri seorang pecandu, karena di satu sisi ada bagian dirinya yang sangat ingin menggunakan narkoba, sementara ada bagian lain dalam dirinya yang mencegahnya. Sugesti inilah yang seringkali menyebabkan pecandu relapse. Sugesti ini tidak bisa hilang dan tidak bisa disembuhkan, karena inilah yang membedakan seorang pecandu dengan orang-orang yang bukan pecandu. 94

Irsyad : Jurnal Bimbingan, Penyuluhan, Konseling, dan Psikoterapi Islam 7(1) (2019) 85-104 
Orang-orang yang bukan pecandu dapat menghentikan penggunaannya kapan saja, tanpa ada sugesti, tetapi para pecandu akan tetap memiliki sugesti bahkan saat hidupnya sudah bisa dibilang normal kembali. Sugesti memang tidak bisa disembuhkan, tetapi kita dapat merubah cara kita bereaksi atau merespon terhadap sugesti itu.

Dampak mental yang lain adalah pikiran dan perilaku obsesif kompulsif, serta tindakan impulsif. Pikiran seorang pecandu menjadi terobsesi pada narkoba dan penggunaan narkoba. Narkoba adalah satu-satunya hal yang ada didalam pikirannya. Ia akan menggunakan semua daya pikirannya untuk memikirkan cara yang tercepat untuk mendapatkan uang untuk membeli narkoba. Tetapi ia tidak pernah memikirkan dampak dari tindakan yang dilakukannya, seperti mencuri, berbohong, atau sharing needle karena perilakunya selalu impulsif, tanpa pernah dipikirkan terlebih dahulu. Ia juga selalu berpikir dan berperilaku kompulsif, dalam artian ia selalu mengulangi kesalahan-kesalahan yang sama. Misalnya, seorang pecandu yang sudah keluar dari sebuah tempat pemulihan sudah mengetahui bahwa ia tidak bisa mengendalikan penggunaan narkobanya, tetapi saat sugestinya muncul, ia akan berpikir bahwa mungkin sekarang ia sudah bisa mengendalikan penggunaannya, dan akhirnya kembali menggunakan narkoba hanya untuk menemukan bahwa ia memang tidak bisa mengendalikan penggunaannya! Bisa dikatakan bahwa dampak mental dari narkoba adalah mematikan akal sehat para penggunanya, terutama yang sudah dalam tahap kecanduan. Ini semua membuktikan bahwa penyakit adiksi adalah penyakit yang licik, dan sangat berbahaya. Adiksi terhadap narkoba membuat seseorang kehilangan kendali terhadap emosinya. Seorang pecandu acapkali bertindak secara impuls, mengikuti dorongan emosi apapun yang muncul dalam dirinya. Dan perubahan yang muncul ini bukan perubahan ringan, karena pecandu adalah orang-orang yang memiliki perasaan dan emosi yang sangat mendalam. Para pecandu seringkali diselimuti oleh perasaan bersalah, perasaan tidak berguna, dan depresi mendalam yang seringkali membuatnya berpikir untuk melakukan tindakan bunuh diri.

Secara psikologis kondisi mereka sangat rentan terkena narkoba, apalagi jika didukung oleh lingkungan yang tidak sehat. Perkenalan awal mereka terhadap narkoba biasanya terjadi karena pengaruh teman sebaya yang notabene sudah pecandu narkoba. Sedangkan faktor yang lain adalah kurangnya penanaman nilai-nilai agama dan pendidikan yang diberikan orang tuanya terhadap anak-anaknya. Dengan kurangnya nilai-nilai agama inilah yang pada akhirnya seorang anak tidak dapat mengetahui mana yang hak dan bathil. Maka dari itu dari beberapa narasumber yang telah diwawancarai menyatakan latar belakang mereka mengapa bisa masuk pondok pesantren memiliki alasan yang berbeda. Ada yang menyatakan kemauan mereka sendiri dan ada pula mendapat 


\section{A. Rahman}

dorongan semangat dari keluarga mereka.

Berbagai macam dampak yang disebabkan oleh penyalahgunaan narkoba. Di antaranya adalah dampak terhadap diri sendiri secara fisik, mental, sosial, dan spiritual, dampak terhadap lingkungan, dan dampak terhadap bangsa (Martono, 2006: 3-4).

\section{Model Konseling Islam}

Fokus dalam penelitian ini adalah mencari dan mengamati sebah model konseling islam di pondok remaja inabah yang didalamnya terdapat proses rehabilitasi menggunakan metode islami yaitu inabah yang berdasarkan pada proses penyadaran dalam Thariqaat Qadariyyah wa Naqsabandiyah (TQN) serta pelaksanaan layanan konseling individu dan kelompok. Dengan demikian dapat diketahui model konseling islam termasuk model bimbingan penanggulangan terhadap pecandu dan korban penyalahgunaan narkoba, serta model bimbingan kepribadian mengenai kesehatan mental dan mengatasi krisis batiniyah dalam pemulihan korban penyalahgunaan narkoba dengan memperhatikan unsur-unsur model konseling islam.

Pertama, dasar pemikiran. Orang dengan ketergantungan narkoba merupakan penderita yang memerlukan pertolongan serta pemulihan. Oleh karena itu sikap yang tepat terhadap penyalahguna narkoba adalah dengan rehabilitasi. Merujuk pada konsep penyadaran diri dalam arti menanamkan kesadaran akan hubungan seorang hamba dengan Penciptanya. Penyadaran diri dari kelalaian manusia terhadap hakikat diri dan Tuhannya, penyadaran diri dari kelalaian terhadap hakikat serta tujuan hidupnya; darimana ia berasal, untuk apa ia hidup dan akan kemana kembalinya setelah kehidupan ini. Akibat kelalaian manusia akan hakikat diri dan Tuhannya ini, banyak manusia tersesat dalam perjalanan hidupnya dan tidak mampu menjalani hidup dengan bahagia. Terutama hal ini terjadi pada setiap pengguna dan pecandu sebagai korban penyalahgunaan narkoba.

Penerapan rehabilitasi di Pondok Remaja Inabah yang utama adalah agar Anak Bina/ Klien dikembalikan kesadarannya agar tidak lupa kepada hakikat diri dan Tuhannya serta memiliki arah hidup yang jelas dan mampu mengembalikan diri ke jalan yang benar serta diridhai Allah. Proses penyadaran yang digunakan dalam Pesantren Remaja Inabah ini diistilahkan dalam Thariqaat Qaadiriyyah waNaqsyabandiyyah (TQN) sebagai taqkiyatun nafsi atau pembersihan jiwa dari berbagai penyakit atau kotoran hati sumber kerusakan moral dan pribadi seseorang yang pada gilirannya dapat merusak jiwa (psike) bahkan fisik seorang manusia (soma), sehingga muncul istilah penyakit psikosomatis. Penyadaran diri dalam Thariqaat Qaadiriyyah wa-Naqsyabandiyyah (TQN) menggunakan pendekatan sufistik dengan cara mendekatkan diri kepada Allah memperbanyak ibadah kepada-Nya dan mengisi sebanyak mungkin alam kesadaran manusia 
dengan nama atau asma Allah, serta menjauhkan diri dari dorongan dan kecendrungan jiwa rendah.

Rehabilitasi Pondok Remaja Inabah merupakan salah satu proses rehabilitasi yang memperhatikan pemulihan pada seluruh aspek kehidupan anak binanya, baik secara fisik, psikis, sosial, dan tentunya yang paling utama ialah aspek spritual. Aspek spiritual disini menjadi sasaran utama dalam pelaksanaan rehabilitasi metode inabah dengan mengacu pada Tariqaat Qadariyyah $W a$ Naqsabandiyyah (TQN), dan mampu mempengaruhi pada pemulihan aspek lainnya (fisik, psikis, dan sosial). Dan rangkaian serta proses pemberian bantuan penyadaran diri pada korban penyalahguna narkoba merupakan model konseling Islam.

Kedua, visi penerapan konseling Islam "Terwujudnya program layanan dan pembinaan unggulan dalam menghasilkan anak bina yang berakhlaq mulia". Dengan misinya : (1) Melestarikan, mengamankan dan mengamalkan Metode Pembinaan Mental korban penyalahgunaan Narkotika dan Zat Adiktif lainnya, yakni Thariqaat Qadiriyah wa Naqsabandiyah (TQN) Pondok Pesantren Suryalaya dengan segala bentuk, sistem, cara dan metode 'amaliyyahh ibadahnya. (2) Membantu memulihkan kesadaran, menyembuhkan dan mendidik para penyalahguna dan korban penyalahgunaan narkoba, sehingga mereka kembali ke jalan yang benar. (3) Membantu para pecandu narkoba, penyalahguna dan korban penyalahgunaan narkoba yang telah mendapatkan layanan rehabilitasi dapat kembali produktif dan berfungsi sosial dalam kehidupannya secara normal dan wajar. (4) Melaksankan kewajiban amar ma'ruf nahyi munkar khususnya dalam usaha memerangi musush generasi bangsa penyebab kerusakan mental dan moral manusia yang semakin merasuk dan merusak akhlak serta sistem peradaban bangsa Indonesia. (5) Ikut serta mensukseskan pembangunan nasional bidang fisik materiil dan mental spiritual bagi generasi bangsa,khususnya Program Nasional Indonesia Bebas Narkoba. Dan tujuannya adalah untuk mengembalikan, memulihkan, menyembuhkan kondisi para pecandu, penyalahguna, dan korban penyalahgunaan narkoba atau klien/anak bina dari perilaku maksiat (jalan sesat) kepada perilaku ta'at (jalan Allah) dan dapat meraih ridha Allah SWT (Ilaabii Anta Maqshudii Wa Ridhaaka Matblubii A'tbinii Mahabbataka Wama'rifataka).

Ketiga, metode dan teknik yang digunakan dalam memulihkan orang yang ketergantungan narkoba merujuk pada konsep metode penyadaran diri dan pembersihan diri yang diistilahkan dalam Thariqaat Qadiriyyah wa Naqsabandiyah (TQN) sebagai tarkiyatun nafsi, sehingga metode utama yang digunakan ialah metode ibadah pendekatan sufistik dengan cara mendekatkan diri kepada Allah, memperbanyak amaliyyah ibadah, mengisi sebanyak mungkin alam kesadaran manusia dengan asma Allah, serta menjauhkan diri dari dorongan dan 


\section{A. Rahman}

kecenderungan jiwa rendah. Dengan beberapa teknik yang digunakan di Inabah, diantaranya: Talqin dan Bai'at, Mandi Taubat, Penegakan Shalat Wajib dan Sunnah, Driker khafiy dan Jahr, Khataman Al-Quran, Manakiban, Ziarah, serta dukungan teknik layanan konseling individual dan kelompok.

Keempat, materi konseling Islam untuk rehabilitasi korban penyalahguna narkoba di Pondok Remaja Inabah XIV Garut ialah materi-materi keagamaan berupa materi aqidah, materi fiqh, dan materi akhlaq. Selain itu juga disambung dengan materi-materi kegamaan lainnya, dan materi sosial pendidikan juga dalam menyiapkan kesiapan mental anak bina setelah keluar dari Pondok Remaja Inabah XIV Garut.

Kelima, media yang digunakan dalam pelaksanaan konseling Islam untuk rehabilitasi korban penyalahguna narkoba di Pondok Remaja Inabah XIV Garut berupa media sarana prasarana secara fisik yang meliputi perangkat adiminstrasi, tempat mandi taubat, ruang konseling, dan pembina. Serta media non-fisik berupa kurikulum inabah.

Keenam, proses dan tahapan dalam pelaksanaan konseling Islam untuk rehabilitasi korban penyalahguna narkoba di Pondok Remaja Inabah XIV Garut ialah anak bina yang baru datang ke Pondok Remaja Inabah XIV melakukan penalqinan dan bai'at yang dipimpin oleh pimpinan sekaligus pembina juga, setelahnya anak bina melakukan serangkaian program layanan rehabilitasi yang dilakukan tiga kali 40 hari.

Pada bulan pertama, pendekatan rehabilitasi dilakukan secara medis diawal dengan melaksanakan proses klinis dan pemutusan penghilangan terhadap narkoba (Detoksifikasi). Hal ini dilakukan agar pembina mengetahui kandungan kadar narkoba yang ada didalam tubuh anak bina. Pada tahap ini anak bina diberikan pengawasan khusus dengan memutuskan akses hubungan kehidupan luarnya, hal ini dilakukan agar anak bina tidak dapat meninggalkan pondok, dan terfokus pada proses rehabilitasi. Anak bina juga mulai dididik dan dilakukan intervensi rehabilitasi metode inabah, dari mulai pelaksanaan mandi, dzikir, dan sholat.

Pada bulan kedua, anak bina melaksanakan metode inabah amaliyyah ibadah dengan intensif, yaitu Mandi taubat, penegakan sholat wajib maupun sunnah, dzikir khofiy dan jahr, khataman alquran, puasa, dan manakiban. Hal ini dilakukan dengan tujuan agar anak bina sembuh total dari kadar narkoba dengan cara pembersihan jiwa dengan bertaubat memohon ampun kepada Allah SWT dan senantiasa tidak terulang lagi sehingga dalam pribadi dan jiwa mereka kemali kepada ajaran agama Islam.

Pada bulan ketiga, anak bina dikonseling secara intensif oleh pembina untuk lebih memantapkan diri dan memahami pribadi mereka kepada jalan yang benar sekaligus meninggalkan jalan yang sesat dan merugikan bagi diri, keluarga dan lingkungannya. 
Ketujuh, evaluasi. Seluruh civitas pengurus Pondok Remaja Inabah XIV mengadakan evaluasi seluruh kegiatan setiap satu kali dalam seminggu. Pada evaluasi ini membicarakan mengenai hasil assesmen dan konseling yang dilakukan pada anak bina, pemberian intervensi metode rehabilitasi inabah, dan hasil pengawasan setiap pengurus pada anak bina agar dapat mengetahui perkembangan setiap anak bina. Evaluasi ini bertujuan untuk langkah penanganan yang dilakukan pembina pada anak bina, juga untuk melihat sejauh mana pemulihan yang dialami oleh anak bina.

Model bimbingan konseling Islam ini merupakan suatu pola atau suatu contoh kerja sistematis dan umum atau suatu pola dan bentuk dalam penyampaian pengetahuan atau bimbingan tertentu dari suatu ilmu agar yang dibimbing dapat mengetahui, memahami, mempergunakan dan mengamalkannya (Darajat, 1995: 1).

\section{Hasil Penerapan Model Koseling Islam}

Rehabilitasi narkoba adalah sebuah tingkatan represif yang dilakukan bagi pecandu narkoba. Tindakan rehabilitasi ditujukan kepada korban dari penyalahgunaan narkoba untuk memulihkan atau mengembangkan kemampuan fisik, mental, dan sosial penderit yang bersangkutan. Selain untuk memulihkan, rehabilitasi juga sebagai pengobatan atau perawatan bagi para pecandu narkoba, agar para pecandu dapat sembuh dari kecanduannya terhadap narkotika. Rehabilitasi memiliki 2 bagian yaitu rehabilitasi secara medis dan rehabilitasi sosial. Dengan upaya-upaya pembinaan dan pengobatan tersebut diharapkan nantinya korban penyalahgunaan narkotika dapat kembali normal dan berperilaku baik dalam kehidupan bermasyarakat. khususnya pelaksanaan rehabilitasi di Pondok Remaja Inabah XIV Garut.

Kegiatan rehabilitasi ini dilaksanakan dengan waktu pokok tiga kali 40 hari. Pada bulan pertama, pendekatan rehabilitasi dilakukan secara medis diawal dengan melaksanakan proses klinis dan pemutusan penghilangan terhadap narkoba (Detoksifikasi). Hal ini dilakukan agar pembina mengetahui kandungan kadar narkoba yang ada didalam tubuh anak bina. Pada tahap ini anak bina diberikan pengawasan khusus dengan memutuskan akses hubungan kehidupan luarnya, hal ini dilakukan agar anak bina tidak dapat meninggalkan pondok, dan terfokus pada proses rehabilitasi.

Pada bulan kedua, anak bina mulai dididik dan melakukan intervensi rehabilitasi metode inabah, dari mulai pelaksanaan mandi, dzikir, dan sholat. Hal ini dilakukan dengan tujuan agar anak bina sembuh total dari kadar narkoba dengan cara pembersihan jiwa dengan bertaubat memohon ampun kepada Allah SWT dan senantiasa tidak terulang lagi sehingga dalam pribadi dan jiwa mereka kemali kepada ajaran agama Islam.

Pada bulan ketiga, anak bina diterapi secara intensif oleh pembina untuk 


\section{A. Rahman}

lebih memantapkan diri dan memahami pribadi mereka kepada jalan yang benar sekaligus meninggalkan jalan yang sesat dan merugikan bagi diri, keluarga dan lingkungannya. Hal ini terbukti ketika anak bina ditanyakan pendapatnya tentang penggunaan narkoba, mereka yakin tidak akan mengulangi lagi bahkan ada yang sampai membenci narkoba. Apabila hasil dari pembinaan selama tiga kali 40 hari tersebut dirasa kurang dan si anak bina belum mengalami perubahan yang cukup signifikan, maka tidak menutup kemungkinan anak bina tinggal lebih lama dari proses waktu yang ditetapkan. Seluruh civitas pengurus Pondok Remaja Inabah XIV mengadakan evaluasi seluruh kegiatan setiap satu kali dalam seminggu. Pada evaluasi ini membicarakan mengenai hasil assesmen dan konseling yang dilakukan pada anak bina, pemberian intervensi metode rehabilitasi inabah, dan hasil pengawasan setiap pengurus pada anak bina agar dapat mengetahui perkembangan setiap anak bina.

Anak bina yang diperbolehkan untuk keluar dari Pondok pulang kembali berkumpul dengan keluarga dan telah bisa kembali pada kehidupan bermasyarakat tidak dilakukan dengan begitu saja dari pihak Pondok Remaja Inabah XIV. Tetap ada monitoring dan pengawasan pasca rehabilitasi. Pada tahap ini disebut pembinaan lanjutan, pembina pondok tetap memonitoring kegiatan-kegiatan anak bina yang telah keluar dan mengontrol dengan baik aktivitas, perilaku, dan perbuatan sehari-hari yang dijalaninya. Dengan tetap menjalin komunikasi baik dengan anak bina langsung, maupun dengan keluarga yang bersangkutan. Hal ini dimudahkan, apalagi dengan kemajuan media sosial pada zaman sekarang ini, sehingga pengawasan juga bisa dirasa lebih mudah dilakukan.

Untuk mengetahui hasil yang dicapai dalam penerapan model bimbingan dan konseling islam untuk rehabilitasi korban penyalahgunaan narkoba di Pondok Remaja Inabah XIV Garut peneliti mengajukan pertanyaan penelitian dengan mengadakan wawancara langsung kepada sejumlah responden yaitu anak bina, pembina dan pimpinan di pondok remaja inabah XIV Garut yang digunakan dan dikembangkan. Dari wawancara tersebut peneliti memperoleh informasi yang berharga dan data-data sekaligus mengolahnya secara matang yang terkait dengan model konseling islam dan unsur-unsur model yang terdiri dari landasan pemikiran, visi misi, tujuan, metode dan teknik, media, materi, langkah-langkah konseling islam, dan evaluasi. Hal ini ditunjukan dengan kondisi anak bina setelah menjalani program layanan rehabilitasi di Pondok Remaja Inabah XIV terdapat beberapa perubahan yang terjadi pada diri anak bina, diantaranya :

Tabel 2. Kondisi Anak Bina Setelah Rehabilitasi

\begin{tabular}{lcc}
\hline No. & Aspek Kondisi & Ciri-Ciri Kondisi \\
\hline 1. & Kondisi Biologis & Dampak pada system syaraf (neurologis) seperti: sudah tidak \\
\hline
\end{tabular}


pernah mengalami kejang-kejang, dan terhindar dari gangguan kesadaran;

Dampak pada kulit (dermatologis) seperti: penanahan (abses), alergi, dan eksim yang dialami sembuh, dan warna kulit terasa lebih bercahaya;

Dampak pada paru-paru (pulmoner) seperti: merasa bernafas lebih ringan dan tidak berat lagi;

Jarang sakit kepala, serta tidak lagi mual-mual dan muntah, murus-murus, dan sulit tidur;

Tubuh lebih bugar dan sehat, serta berat badan bertambah menjadi lebih ideal.

2. Kondisi

Psikologis

3. Kondisi Sosial

4.

Tidak lagi berhalusinasi;

Lebih cepat dan gesit dalam bekerja, hati tidak merasa kosong dan hampa lagi sehingga sudah jarang cemas, tegang, dan khawatir tiba-tiba;

Lebih percaya diri, dapat terbuka baik pada diri sendiri dan orang-orang sekitar, serta senantiasa positive thinking;

Hati merasa lebih tenang;

Dapat lebih fokus dan konsentrasi.

Dapat menyesuaikan diri dengan lingkungan sekitarnya;

Lebih aktif dalam berinteraksi dengan orang-orang sekitar;

Bisa ikut berkontribusi kembali dalam membantu

perekonomian keluarga, sehingga tidak menjadi beban;

Dapat memulai kembali lembaran kehidupan yang baru dengan positif, seperti melanjutkan pendidikan, serta pekerjaan/usaha.

Kondisi Spiritual Melakukan peribadahan dengan giat dan rajin;

Senantiasa bertaubat dan mengintrospeksi diri karena Allah SWT

Sumber : Hasil wawancara dan observasi

Tabel diatas menerangkan kondisi anak bina setelah mengikuti layanan rehabilitasi di Pondok Remaja Inabah XIV Garut, anak bina merasakan banyak hal-hal positif yang terjadi pada dirinya, hal ini dirasakannya baik secara fisik, psikis, sosial maupun spiritual. Bagi anak bina yang telah bermukim cukup lama (lebih dari 120 hari) merasakan perubahan yang drastis didalam hidupnya. Secara fisik, anak bina tersebut meyakini bahwa kondisinya jauh lebih sehat lebih bugar, secara psikis lebih tenang, secara sosial sudah bisa kembali berinteraksi secara aktif didalam kehidupan bermasyarakat, semangat bekerja meningkat juga jelas 


\section{A. Rahman}

dari segi spiritual yang senantiasa ingin selalu berdekat diri pada Allah SW'T, dan bahkan sering kali lebih betah bermukim di Pondok dari pada harus kembali. Hal ini pun mulai dirasakan bagi anak bina yang masih menjalani proses rehabilitasi (tiga bulan pertama), hal-hal positif juga terjadi pada diri, secara fisik ketergantungan pada obat terlarang tersebut hilang, hatinya lebih tenang, mulai banyak berintrospeksi diri, mulai membuka diri, memberanikan diri untuk bercerita tentang hidupnya, bahkan giat dan rajin beribadah, dan mendekatkan diri pada Allah SW'T.

Sehingga dari hasil penelitian bahwa program layanan rehabilitasi narkoba di Pondok Remaja Inabah yang menjadikan pendekatan keagamaan sebagai metode inti dalam menyembuhkan anak bina pecandu dan korban penyalahguna narkoba menjadi cukup efektif dan efisien. Hal ini ditunjukkan dengan kondisikondisi positif yang dialami oleh para anak bina setelah mengikuti proses rehabilitasi di Pondok Remaja Inabah XIV Garut.

Karena itulah Korban penyalahgunaan narkoba hakikatnya memerlukan bimbingan, bantuan, dan pertolongan untuk perawatan, penyembuhan guna menumbuhkan kembali Akhláq-al-Karímah, meningkatkan ketaqwaan, dan terlepas dari bayang-bayang Narkoba, serta ingat kepada Sang Penciptanya, yakni Allah SWT. Konseling Islam merupakan salah satu upaya pemecahan masalah dengan memberikan bantuan kepada orang yang mengalami kesulitan, baik lahiriyah maupun batiniyah, yang menyangkut kehidupan sekarang maupun kehidupan yang akan datang. Bantuan tersebut berupa pertolongan dibidang mental spiritual, dengan maksud agar orang mampu menyelesaikan permasalahannya dengan kemampuan yang ada pada dirinya, dengan kekuatan iman dan taqwa kepada Allah SWT (Arifin, 1982: 2).

\section{PENUTUP}

Penyalahgunaan narkoba bukan hanya dipandang sebagai kejahatan, namun merupakan penyakit moral masyarakat. Pelakunya tidak lagi dipandang sebagai kriminal, melainkan sebagai korban, yaitu penderita yang memerlukan pertolongan dan bimbingan. Pendekatan agama dalam hal ini adalah yang utama. Karena korban narkoba merupakan klien yang memiliki sakit selain fisik juga mental. Maka harus ada penanganan khusus mulai dari medis sampai spiritual. Penanaman nilai-nilai agama islam bagi para pecandu adalah salah satu metode terapi yang berkembang saat ini. Karena dalam nilai-nilai agama islam secara praktek dianggap mampu mengobati berbagai macam penyakit dari penyakit raga maupun jiwa. Konseling Islam merupakan salah satu upaya pemecahan masalah, dan bantuan tersebut berupa pertolongan dibidang mental spiritual, dengan maksud agar orang mampu menyelesaikan permasalahannya dengan 
kemampuan yang ada pada dirinya, dengan kekuatan iman dan taqwa kepada Allah SW'T.

Dari sekian banyak pembahasan yang telah dipaparkan dapat ditarik kesimpulan sebagai berikut: pertama, kondisi yang dirasakan para korban penyalahguna narkoba (anak bina) di Pondok Remaja Inabah XIV Garut secara fisik mengalami gangguan pada sistem saraf (seperti gangguan kesadaran, dan kejang-kejang), gangguan pada kulit (abses dan eksim), gangguan pada fungsi pernapasan. Secara psikologis korban penyalahguna narkoba memiliki sering tegang dan gelisah, hilang kepercayaan diri, agitatif dan bertingkah laku brutal, sulit berkonsentrasi bahkan depresi. Secara sosial korban penyalahguna narkoba itu anti sosial, memiliki kecenderungan asusila, pembuat masalah, dan di cap memiliki masa depan yang suram. Secara spiritual, mereka tidak mempercayai adanya Tuhan serta tidak pernah apalagi mengetahui tata cara pelaksanaan ibadah, sehingga banyak dari mereka yang tersesat (dari jalan Agama).

Kedua, model konseling Islam untuk rehabilitasi korban penyalahgunaan narkoba di Pondok Remaja Inabah XIV Garut merupakan model bimbingan konseling dan kepribadian serta model penanggulangan dengan komponen model yang terdiri dari unsur-unsur model yang terdiri dari landasan pemikiran, visi misi, tujuan, metode dan teknik, media, materi, langkah-langkah konseling islam, dan evaluasi.

Ketiga, Hasil yang dicapai dalam penerapan model bimbingan dan konseling islam untuk rehabilitasi korban penyalahgunaan narkoba di Pondok Remaja Inabah XIV Garut, hal ini ditunjukan dengan kondisi anak bina setelah menjalani program layanan rehabilitasi di Pondok Remaja Inabah XIV terdapat beberapa perubahan yang terjadi pada diri anak bina. Secara fisik, mereka tidak lagi mengalami gangguan saraf, gangguan pernafasan, bahkan sembuh dari gangguan kulit. Secara psikis, mereka merasa tenang (tidak cemas dan gelisah lagi), mulai terbuka, dapat lebih gesit berkegiatan, senantiasa berpikiran positif, dan lebih percaya diri. Secara sosial, anak bina mulai bisa berkomunikasi aktif kembali dengan lingkungan sekitarnya, dan tidak apatis. Sedangkan secara spiritual, anak bina melakukan peribadahan dengan giat dan rajin, serta senantiasa bertaubat dan mengintrospeksi diri karena Allah SWTT.

Berdasarkan kesimpulan yang telah dikemukakan, maka penulis ingin menyampaikan saran/rekomendasi untuk penelitian selanjutnya, dengan berbagai macam problematika yang terjadi di masyarakat, khususnya mahasiswa BKI diharapkan mampu membantu memberi kontribusi dalam menyelesaikan berbagai masalah tersebut. Hal ini termasuk pada permasalahan penanggulangan korban penyalahguna narkoba, sehingga tidak hanya teori yang dijelaskan dan pemahaman yang ditanamkan tetapi memiliki pengalaman praktek pun akan memudahkan kami merasakan begitu besarnya khazanah keilmuan konseling 
M. A. Rahman

Islam yang selama ini telah dipelajari di bangku perkuliahan.

\section{DAFTAR PUSTAKA}

Abidin, Z. (2003). Aplikasi Ilmu-ilmu Agama. Yoyakarta: PPM IAIN Sunan Kalijaga Yogyakarta.

Adz-Dzaki, H.B. (2006). Konseling dan Psikoterapi Islam. Yogyakarta: Fajar Pustaka Baru.

Amin, S.M. (2010). Bimbingan Dan Konseling Islam. Jakarta: Hamzah.

Arifin, HM. (1982). Pokok-pokok fikiran tentang bimbingan dan penyuluhan agama. Jakarta: Bulan.

Arifin, I.Z. (2009). Bimbingan Penyuluban Islam Pengembangan Da'wah: Bimbingan Psikoterapi Islam. Jakarta: Raja Grafindo Persada.

BNN, PUSLITKES UI. (2017). (Ringkasan Eksekutif) Hasil Survei Penyalahgunaan dan Peredaran Gelap Narkoba pada Kelompok Pelajar dan Mahasiswa di 18 Provinsi tahun 2016. Jakarta: Puslidatin BNN.

Daradjat, Z. (2011). Metodik Khusus Pengajaran Agama Islam. Jakarta: Bumi Aksara.

Farid, A. (2015). Model bimbingan konseling Islam anwar sutoyo dalam mengatasi kenakalan remaja dalam Konseling Religi 6(2).

Gudnanto, G. (2015). Model bimbingan dan konseling islami untuk meningkatkan konsep diri siswa dalam Refleksi Edukatika 5(1).

Hajir, T. (2012). Konseling Islam: Studi terhadap Posisi dan Peta Keilmuan dalam Ilmu Dakwah: Academic Journal for Homiletic Studies, 6(20), 226-248.

Hasyim, F \& Mulyono. (2010). Bimbingan \& Konseling Religius. Jogjakarta: Ar-Ruzz Media.

Kibtyah, M. (2015). Pendekatan Bimbingan dan Konseling bagi Korban Penyalahguna Narkoba. dalam Jurnal Ilmu Dakwab: Media Pengembangan Ilmu dan Teknik Dakwah UIN Walisongo Semarang, 35(1), 52-77.

Lubis, S.A. (2007). Konseling Islami (Kiayi dan Pesantren). Yogyakarta: eLSAQ Press.

Martono, L.H. 2006. Membantu Pemulihan Pecandu Narkoba dan Keluarganya. Jakarta: Balai Pustaka.

Nisa, A. (2017). Model bimbingan dan konseling Islam psikoanalisis berbasis islam untuk mengurangi kecemasan moral pada remaja dalam Tazkiyah 6(1).

Rosmiati, C. (2009). Metode Bimbingan Keagamaan bagi Pengguna Narkotika, Psikotropika dan Zat Adiktif (NAPZA). Skripsi, Jurusan Bimbingan dan Konseling Islam, UIN Sunan Gunung Djati, Bandung.

Saepulrahim, A. (2016). Manajemen Bimbingan dan Konseling Islam. Bandung: Mimbar Pustaka.

Winkel, W.S. (1997). Bimbingan dan Konseling. Jakarta: Grasindo. 